\title{
Chapter 3 \\ Provisioning of Mussel Seed and Its Efficient Use in Culture
}

\author{
P. Kamermans and J. J. Capelle
}

\begin{abstract}
Mussel culture largely depends on seed and feed from the natural environment. This paper focusses on seed provisioning and efficient use of these resources in mussel production. Approaches and technologies for seed supply and efficient use of seed in mussel production are described for the different culture techniques. This includes potential interactions and conflicts with the natural environment. Three methods are used to provide seed: wild harvest, use of suspended collectors and hatchery production. Harvest of wild seed from seaweed (in New Zealand) or natural beds is still a major source for culture in some areas, costs are low but provisioning is often unreliable. Most research concerning spat collection deals with comparison of different types of suspended collectors, settlement cues and problems with biofouling. Hatchery seed is more expensive, but hatcheries provide the opportunity for selective breeding and triploid production giving the product an added value. The challenge is to bring hatchery production costs more in line with the actual sale value of mussel seed. Monitoring genetic diversity can give insight in whether collector seed or hatchery seed growth and survival is negatively affected by reduced diversity. Grow-out occurs in bottom culture, bouchot culture and off-bottom longline and raft culture. In bottom-culture, the focus is on developing better seeding techniques, predator control and optimizing culture practices such as timing of relay, substrate use and harvest. For bouchot culture, technical developments are directed to mechanical methods to increase efficiency in size grading, restocking, harvesting and processing. Innovation in growing-out techniques for longline and raft culture are directed towards the investigation of optimal stocking densities, and on material type and configuration of farms. Production efficiency increases from bottom culture to bouchot culture, to rope and raft culture and are related to the sources of mortality and differences in growth rate. Growth rate of mussels is higher in off bottom culture than in on bottom culture and higher when submerged than in intertidal. Mussels from the Perna genus are found to have a higher growth rate but a lower production efficiency than mussels from the Mytilus genus. Efficient use of seed in mussel culture should aim at a reduction of mussel
\end{abstract}

\footnotetext{
P. Kamermans $(\bowtie) \cdot J$ J. J. Capelle

Wageningen UR - Wageningen Marine Research, Yerseke, The Netherlands

e-mail: pauline.kamermans@wur.nl
} 
losses and an increase in growth rates. Important tools are adjusting seeding densities in relation to system design, reducing seeding stress, predator control and applying thinning out or relay.

Keywords Mussels $\cdot$ Seed $\cdot$ Culture $\cdot$ Efficiency

\subsection{Mussel Aquaculture Production}

Mussels are found in large quantities in coastal areas all around the world. Mussels, often organized in patches or in beds, are easily collected and have been an important protein source (an ecosystem good) for mankind since prehistoric times (Erlandson 1988). Mussels are commonly cultured, all that is needed is protection against dislodgement, by using sheltered sites or attachment substrate and protection against predation, supply of oxygen and seston, which is sufficient in most coastal environments. Mussel culture is carried out according to a variety of techniques, often developed in the course of centuries and adapted to the local culture environment. Mussel culture is based on seed and nourishment from the natural environment. This paper focusses on seed provisioning and efficient use of this resource in mussel production.

Global mussel culture mainly concerns two genera (Mytilus and Perna) and 9 species (Mytilus edulis, Mytilus galloprovincialis, Mytilus californianus, Mytilus platensis (also called M. chilensis), Mytilus unguiculatus, Mytilus planulatus, Perna canaliculus, Perna perna and Perna viridis). In addition, a small production of Aulacomya atra and Choromytilus chorus takes place in Chile and Argentina. Mussel production comprises around 1.8 million tonnes with a value of 2.7 billion US dollars (average of 2010-2015, FAO statistics). In 2015, the largest production took place in Asia (1.05 million tonnes), followed by Europe ( 0.50 million tonnes), the Americas (0.25 million tonnes), Oceania and Africa (0.08 million tonnes) (FAO statistics, www.fao.org). The main mussel producing countries are China in Asia, Spain in Europe, Chile in the Americas, New Zealand in Oceania and South Africa in Africa (Table 3.1). Production in China, Chile and New Zealand started in the seventies of the last century and showed a rapid increase (Fig. 3.1). This levelled off for New Zealand around 2005 and continues to increase in China. In Chile production declined fast around 2011, mainly due to problems with toxic algae (Reguera et al. 2014).

\subsection{Culture Techniques and Innovations}

Mussels culture is based on recently settled individuals called spat, or juveniles called seed. This resource is collected in different ways depending on the local circumstances and grow-out methods. In general, three methods are used to harvest spat or seed: wild harvest, use of suspended collectors and hatchery production 
Table 3.1 Mussel aquaculture production (tonnes) in 2015 per species and per country (FAO statistics, www.fao.org)

\begin{tabular}{|c|c|c|}
\hline Species & Country & Tonnes \\
\hline \multirow[t]{16}{*}{ Mytilus e dulis } & France & 61,000 \\
\hline & Netherlands & 54,100 \\
\hline & Canada & 22,725 \\
\hline & United Kingdom & 20,112 \\
\hline & Ireland & 16,015 \\
\hline & Germany & 10,875 \\
\hline & Norway & 2731 \\
\hline & United States of America & 1788 \\
\hline & Sweden & 1525 \\
\hline & Denmark & 1229 \\
\hline & Iceland & 140 \\
\hline & Senegal & 16 \\
\hline & Namibia & 10 \\
\hline & Argentina & 6 \\
\hline & Argentina & 6 \\
\hline & St. Pierre and Miquelon & 3 \\
\hline \multirow[t]{16}{*}{ Mytilus galloprovincialis } & China & 845,038 \\
\hline & Spain & 225,308 \\
\hline & Italy & 63,700 \\
\hline & Greece & 18,628 \\
\hline & France & 14,100 \\
\hline & Bulgaria & 3373 \\
\hline & Portugal & 1315 \\
\hline & South Africa & 950 \\
\hline & Croatia & 746 \\
\hline & Slovenia & 573 \\
\hline & Albania & 295 \\
\hline & Russian Federation & 207 \\
\hline & Montenegro & 189 \\
\hline & Ukraine & 70 \\
\hline & Romania & 35 \\
\hline & Turkey & 3 \\
\hline Mytilus californianus & Mexico & 270 \\
\hline \multirow[t]{2}{*}{ Mytilus platensis } & Chile & 208,707 \\
\hline & Argentina & 6 \\
\hline Mytilus plan u latus & Australia & 3679 \\
\hline Mytilus unguiculatus & Korea, Republic of & 53,536 \\
\hline \multirow[t]{2}{*}{ Perna perna } & Brazil & 18,364 \\
\hline & Venezuela, Boliv Rep of & 1 \\
\hline
\end{tabular}

(continued) 
Table 3.1 (continued)

\begin{tabular}{l|l|r}
\hline Species & Country & Tonnes \\
\hline \multirow{2}{*}{ Perna viridis } & Thailand & 118,775 \\
\cline { 2 - 3 } & Philippines & 15,949 \\
\cline { 2 - 3 } & India & 8700 \\
\cline { 2 - 3 } & Malaysia & 1673 \\
\cline { 2 - 3 } & Cambodia & 1500 \\
\cline { 2 - 3 } & Singapore & 906 \\
\hline Perna canaliculus & New Zealand & 76,811 \\
\hline Aulacomya atra & Chile & 1068 \\
\hline & Argentina & 1581 \\
\hline Choromytilus chorus & Chile & \\
\hline
\end{tabular}

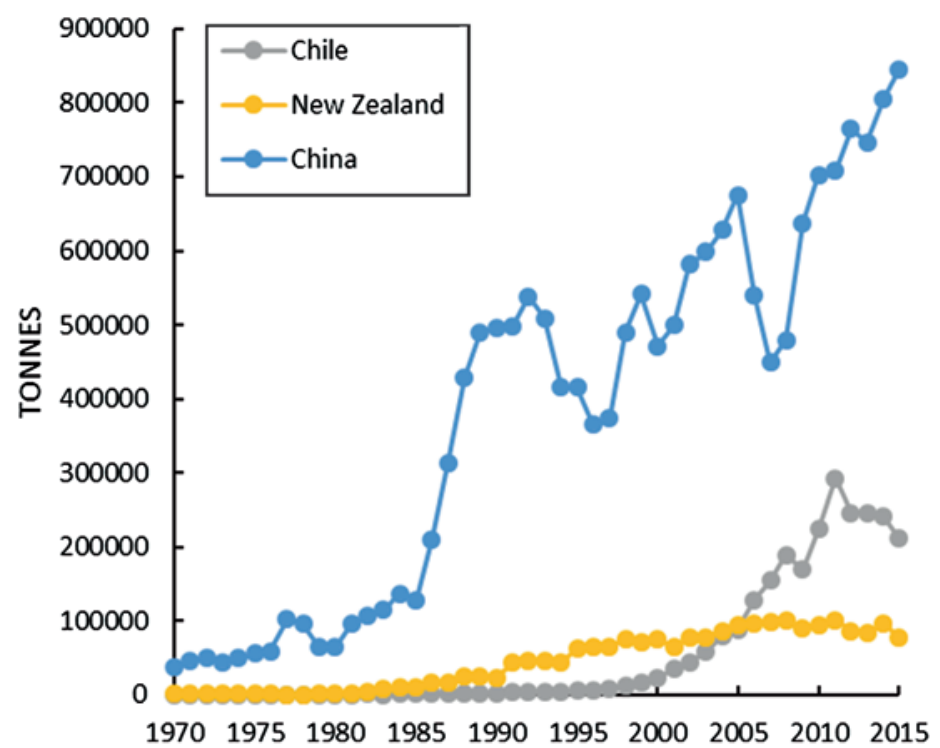

Fig. 3.1 Mussel aquaculture production (tonnes) in Chile, New Zealand and China (FAO statistics, www.fao.org)

(Fig. 3.2). The majority of the grow-out occurs in bottom culture, bouchot culture and off-bottom longline and raft culture (Fig. 3.2).

Each technique to acquire seed has different costs. In general, the least labourintensive method (wild harvest or fishing) has the lowest cost. Fished seed is mostly used in low-effort grow-out such as bottom culture. However, dredging for seed can result in overexploitation. In New Zealand, this made the industry look for alternatives (Jeffs et al. 1999). Longline and raft culture use collected seed. The system to collect seed is usually the same as what is used for grow-out to make it cost efficient. The most expensive method to acquire seed is hatchery production (Kamermans et al. 2013). This is currently only used in longline culture. 


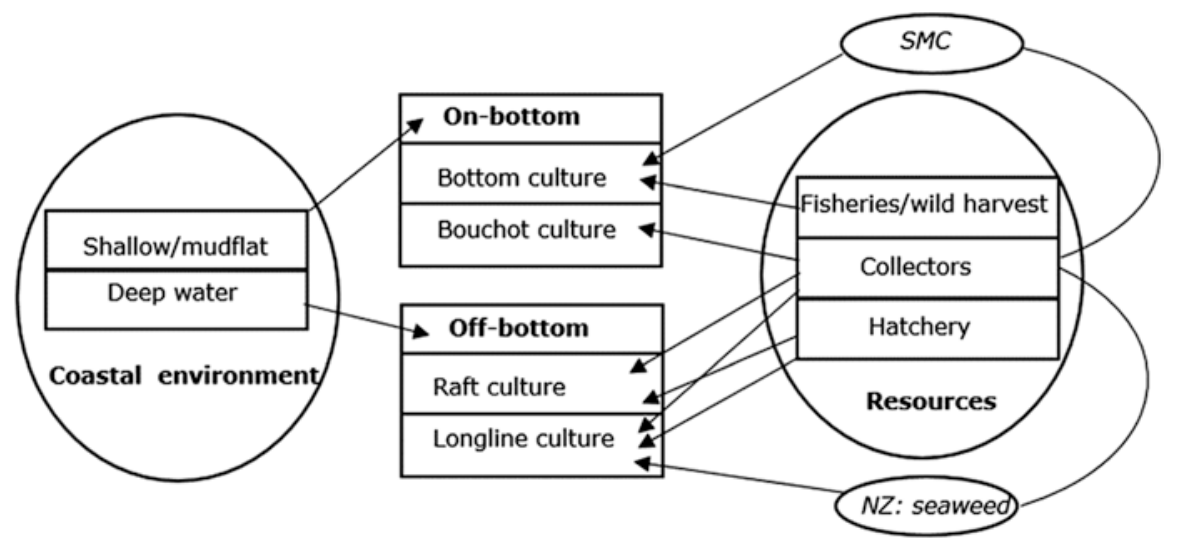

Fig. 3.2 Overview of culture techniques used for mussel production at different environments and for different resources $(\mathrm{SMC}=$ Seed Mussel Collectors, $\mathrm{NZ}=$ New Zealand)

\subsubsection{Bottom Culture}

Mussel bottom culture is typically practised on shallow mudflats in areas where there are extensive naturally occurring mussel seed beds (Fig. 3.3d). In the Netherlands, Germany, UK and Ireland, seed fished from natural beds is the main source for bottom culture (Kamermans and Smaal 2002).

Mussel seed from wild beds are relayed on bottom plots (lease sites) where the mussels are maintained until harvest. Bottom culture is an extensive culture where the mussels are still, to a large extent, subjected to, and dependent on the environment. The Netherlands are the centre of the bottom culture industry in Europe. In the 1970s most of the hand labour was mechanized leading to bulk production of mussels, limited by external factors such as seed availability and culture area. From the 2000s onwards, system innovation took place resulting in the deployment of seed mussel collectors (SMCs, Fig. 3.2). The first tests with seed mussel collectors started in 2000 (Kamermans et al. 2002) and the method showed a rapid development. In 2016 the total yield was about 20,000 tonnes (Capelle 2017). The main drivers for system innovation through SMCs were: (i) to safeguard a steady supply of seed, (ii) to become more sustainable by reducing bottom dredging, and (iii) pressure from green NGOs.

Mussel farmers in the Netherlands are in a transition process from fishing seed from natural beds to harvesting seed with collectors. A stepwise approach is taken: every 2 years a decision on reduction of seed fishing and expansion of the area reserved for seed collection is made based on the annual yield of the collectors. The shift from fishing to using collectors results in a higher mussel biomass in the system, because areas with natural beds are no longer fished and spat survival is enhanced on the collectors. However, competition for food (phytoplankton) between the extra mussel biomass and natural bivalve populations may result in overgrazing 


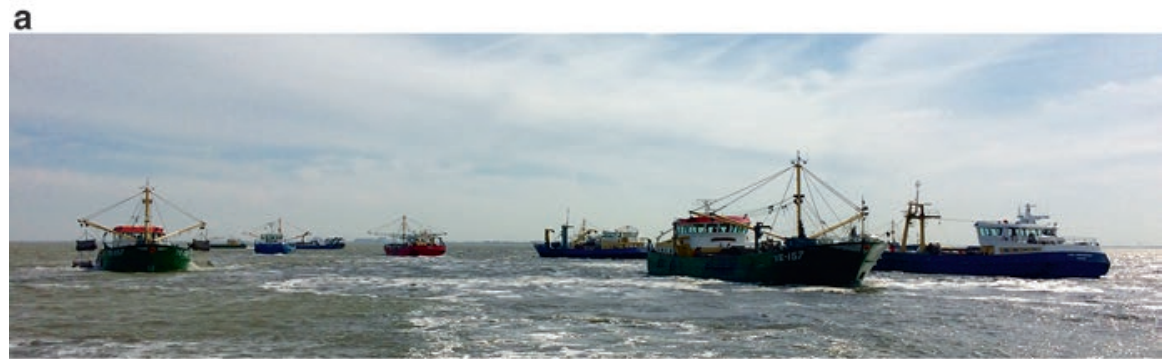

b

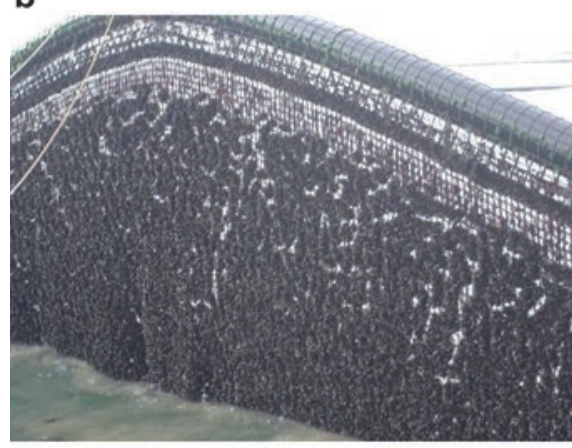

d
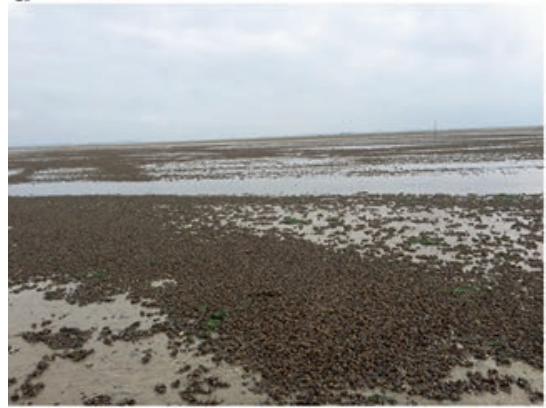

f

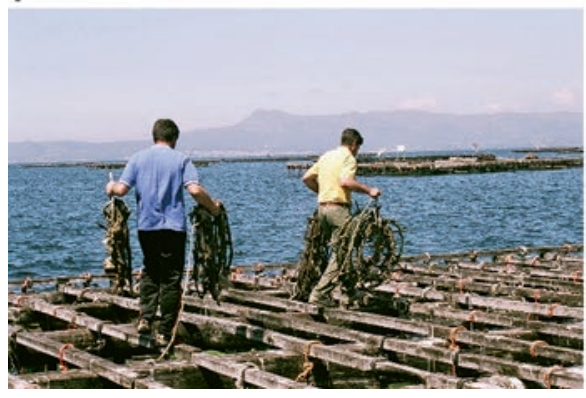

.
C
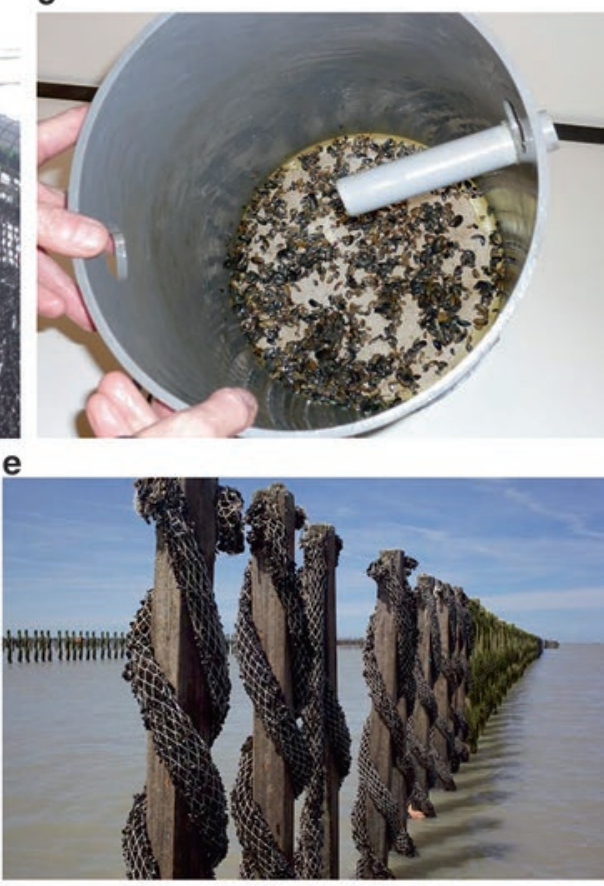

g

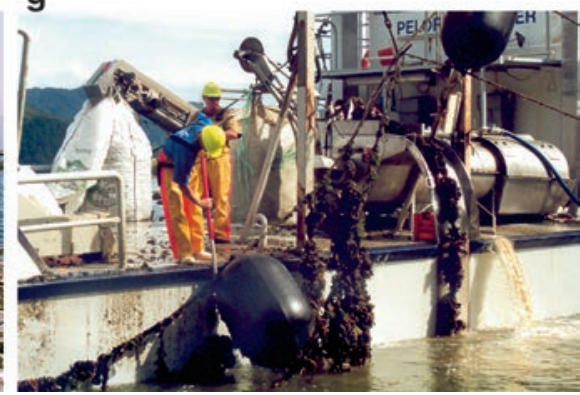

Fig. 3.3 Mussel culture methods: (a) seed fishery, (b) seed mussels collectors, (c) hatchery production, (d) bottom culture, all in The Netherlands, (e) Bouchot culture in France (https://reporterre.net/Les-moules-du-Mont-Saint-Michel-etouffent-la-baie-magnifique), (f) raft culture in Spain and (g) longline culture in New Zealand. Source of pictures: Jacob Capelle (a and d), Aad Smaal (e) and Pauline Kamermans (b, $\mathbf{c}, \mathbf{f}$, and $\mathbf{g}$ ) 
and possibly affect the production capacity. This can have consequences for the yields of cultured bivalves and for organisms that depend on bivalve stocks for their food such as birds. A recent study used time-series data analysis and model calculations to estimate effects on production capacity (Kamermans et al. 2014). In addition, different indicators, such as meat content and growth rates of bivalves for assessment of changes in production capacity for bivalve shellfish were investigated. Kamermans et al. (2014) concluded that when all reserved space for SMCs is exploited at the envisioned end of the transition, expected effects on total bivalve biomass production will be less than or proportional to the increase in biomass of seed from SMC, depending on the area. In some areas, survival of wild, unfished beds is quite limited, due to predation.

The development of new technology that came with SMCs, increased the costs for the resource and will require innovations in other forms, notably an increase in production efficiency (Capelle 2017). Several research projects have been initiated to investigate this topic. Focus is on developing better seeding techniques (Capelle et al. 2014, 2016), predator control using starfish mops (Calderwood et al. 2016) or crab pots (Calderwood et al. 2015) and optimizing culture practices such as timing of relay, substrate use (Christensen et al. 2015) and harvest (Newell et al. 1998; Ferreira et al. 2007; Newell 2007).

\subsubsection{Bouchot Culture}

Bouchot culture (pole culture) is conducted exclusively in France, in areas with flat intertidal mudflats and a relatively large tidal range (Fig. 3.3e). In bouchot culture, mussel seed is collected on ropes, that are placed in horizontal racks in the water column when larvae are present. The ropes are then wound around poles in the intertidal zone for grow-out. Bouchot culture dates back to the thirteenth century and the principles and methods remain largely unchanged. Technical developments are very much restricted to mechanical methods to increase harvest efficiency. Amphibious vehicles are used to harvest the bouchots by means of a cylinder that can be lowered over the poles and scrapes off the mussels (Prou and Goulletquer 2002). Processing, size grading and restocking is also mechanized. Spatial conflicts on bivalve culture with other users is limiting the expansion of bouchot culture in France and has stimulated the development of longline cultures (Prou and Goulletquer 2002).

\subsubsection{Raft and Longline Culture}

In bays with deep waters and bays with rocky shores, rafts and longlines are more commonly used for the grow-out of mussels (Fig. 3.3f, g). Originally developed in the Mediterranean, large-scale raft culture is conducted primarily in Spain, and in 
more recent times, extensively at the northwest coast of Spain, where local upwelling results in a high food availability (Figueiras et al. 2002). In raft culture, mussels are grown on ropes hanging from rafts. In rope or longline culture mussels are grown on ropes attached to floating buoys at the water surface or submerged buoys. Longline culture is globally the most used culture method for mussels. Countries where high biomasses of mussels are produced on longlines are New Zealand, China, Italy and Chile. Culture practices can be summarized as (1) obtaining seed, (2) stocking and growing on rope, (3) restocking after thinning out and outgrow to consumption size. Major issues in off-bottom culture is resource requirement, density dependent growth and losses and biofouling. Self-thinning occurs when biomass increased through growth and food or space becomes limited (Fréchette and Lefaivre 1995; Guiñez 2005).

Seed for off-bottom culture is obtained mainly with seed collectors. However, when natural settlement is scarce other methods are used. For example, in New Zealand the spat for long-line culture is collected on Ninety Mile Beach in the far North of the North Island, where seaweed covered with recently settled natural spat washes upon a beach. Spat density varies from 200 to 2 million per $\mathrm{kg}$ of macroalgae. It is then transported to the culture areas in Coromandel on the North Island and Marlborough Sounds on the South Island (Jeffs et al. 1999).

Most research concerning spat collection deals with settlement cues, comparison of different types of collectors, and problems with biofouling. Understanding the impact of temperature on the rate of larval development is key to predicting the timing of settlement and optimizing mussel seed collection (Filgueira et al. 2015; Jacobs et al. 2014). However, other factors, such as food availability and quality, are important too (Bos et al. 2006; Philippart et al. 2012). Settlement is significantly higher on rough compared to smooth surfaces (Gribben et al. 2011). The most efficient type of SMC has a large surface area, and there is also thought to be a negative relationship between growth and density (e.g. Çelik et al. 2016). Identification and quantification of the presence of mussel larvae is important for optimising the use of suspended seed collectors. With this information timing of deployment can be optimised. Abalde et al. (2003) used mouse monoclonal antibodies to identify $M$. galloprovincialis larvae. The recent development of another identification method involving molecular tools can speed up processing of samples (Ranjith Kumar et al. 2015). After settlement, mussels can show gregarious behaviour on the collector ropes which is influenced by temperature or food availability (e.g. Aghzar et al. 2012). Failure of the collectors, other than insufficient availability of larvae, is mainly due to biofouling. For example, in Canada, the vase tunicate Ciona intestinalis reduces mussel production (Ramsay et al. 2008).

Recently, the focus of research on spat collectors extends towards interactions and conflicts with the natural environment. For example, carrying capacity (see box 1) and genetic diversity are a concern. Larraín et al. (2015) showed that blue mussels in southern Chile, raised from wild-caught seed obtained from relatively few collection sites, have lower genetic diversity than in other countries, and limited genetic differentiation among locations. Transplants of seed from other areas can result in mortality due to adaptation problems (Kautsky et al. 1990). Mussel seed 
has a high adaptive capacity (Widdows et al. 1984; Stirling and Okumuş 1994), but this varies among sources (Tremblay et al. 2011). Thus, adaptation capacity depends on the genetic composition of the stock and local environmental conditions.

Hatchery production of mussels (Fig. 3.3) is not as common as hatchery production of oysters and clams. One of the reasons why hatchery production of mussel seed is less developed for mussels than for other bivalves is that demand for the industry has been limited until now and that very large-scale production is required to make hatchery seed competitive with wild seed. However, commercial hatcheries that produce mussel spat are present (Kamermans et al. 2013). Optimisation of hatchery production is an ongoing process. For example, a recent study by Gui et al. (2016) showed that gill filaments in small Perna canaliculus are not fully developed and capture particles between 15-25 $\mu \mathrm{m}$, while the filaments in bigger mussels are able to capture bacteria-sized particles around $2 \mu \mathrm{m}$. This type of information can be used to select the best algal diet for each life stage.

Generally, mussel hatcheries are only feasible when the price of the product allows it and when alternative sources of seed are scarce or unreliable. A prefeasibility study for the installation of a Chilean mussel seed hatchery showed that seed production in a hatchery was not profitable due to both the low price of Chilean mussels in national and international markets and the high cost of production, mainly associated to the production of microalgae as feed for the larvae (Carrasco 2015). Seed from hatcheries is more expensive, but hatcheries provide the opportunity for selective breeding. Researchers in New Zealand have developed a selective breeding programme for the Greenshell ${ }^{\mathrm{TM}}$ mussel (Perna canaliculus) (Camara and Symonds, 2014). Innovative tools, such as cryopreservation that enables genetic material from selected stock to be stored, are being developed (Gale et al. 2014; Wang et al. 2014). Another advantage of hatchery production is the ability to produce triploids. Recently spawned mussels cannot be sold due to insufficient meat. Triploids are non-maturing mussels which have the advantage that they can be sold year-round. Two EU projects (BLUE SEED and REPROSEED) looked into hatchery production for mussels in Europe, including triploid production and the use of recirculation systems (Kamermans et al. 2013; Blanco and Kamermans 2015). Recently, a new project was started in Scalloway, Shetland, to test the commercial feasibility of producing mussel spat.

Kamermans et al. (2013) identified some areas where changes could be made to bring hatchery production costs more into line with the potential sale value of mussel seed: (i) use low-tech algal culture; (ii) restrict activities to the natural season and take seed into the field at the smallest size possible; (iii) scale up culture volumes during this restricted period of activity. In addition, production of higher added-value products, such as triploids or selective breeding for specific traits, is needed. Otherwise, the production of seed by hatchery techniques will be not be profitable in most cases compared with the cost of obtaining the wild counterparts.

Grow-out with hatchery seed is uncertain when it comes to the origin of the harvested strain. This can be the initially seeded hatchery material or wild recruits. Díaz-Puente et al. (2016) used multiplexed microsatellites to trace back the 
individual origin of a batch of harvested mussels and showed that $98.3 \%$ of the adult harvest came from the original hatchery full-sib family while only $1.7 \%$ of the mussels were recruited from the wild. A microsatellite genetic analysis of M. edulis on the west coast of Canada showed significant reduced genetic diversity in cultured populations compared to the wild population (Gurney-Smith et al. 2017). According to the authors, this is partially due to small effective breeding groups during hatchery propagation, creating genetic drift over successive generations. These results indicate the need for pedigree programs. The European network GENIMPACT evaluated genetic impact of aquaculture activities on native populations. Beaumont et al. (2006) concluded for mussels that it is essential to precisely characterize the true distributions of M. edulis, M. galloprovincialis and their hybrids in all European regions, but especially where mussel aquaculture takes place. Based on such a survey, a series of sites should be identified that are to be genetically monitored on a regular basis to identify any changes in species composition over time. As far as we are aware such monitoring has not started yet. Effects of climate change, such as ocean acidification, may have a serious impact on larval production. A recent study by Waldbusser et al. (2015) showed that larval shell development and growth in Mytilus galloprovincialis are dependent on aragonite saturation state, and not on carbon dioxide partial pressure or $\mathrm{pH}$. With increasing acidification the aragonite saturation state decreases resulting in malformations and reduced growth of D-larvae. Hatcheries have the possibility for chemical manipulation of the seawater in larval tanks.

Innovation in grow-out techniques for longline and raft culture are mainly directed towards the investigation of optimal stocking densities and farm configuration. A few examples are: growing mussels without the need for thinning (PérezCamacho et al. 2013), using size grading (Cubillo et al. 2012), stocking as a function of food availability (Fréchette and Bacher 1998; Grant et al. 2008; Cranford et al. 2008; Strohmeier et al. 2005), and investigating the effect of spacing of mussel ropes (Drapeau et al. 2006; Aure et al. 2007). Effect of the culture structures on food provisioning to the mussels, can reduce mussel quality when scaling up (Rosland et al. 2011). Innovation in raft design is directed to deal with harsh environmental conditions, that results for example in submerged raft designs (Wang et al. 2015) and in optimizing food availability by raft design and orientation (Newell and Richardson 2014).

Biofouling on mussels grown on ropes or nets reduces mussel growth and quality (Sievers et al. 2013). In Canada up to 50\% mortality was observed under heavy tunicate fouling (Locke and Carman 2009). Biofouling organisms that are causing major problems are ascidians, especially Ciona intestinalis, but may also consist of conspecific mussels or other species of mussels, for instance in New Zealand $M$. galloprovincialis is causing large fouling problems on the more valuable $P$. canaliculus. Forrest and Atalah (2017) used a 4-year dataset to calculate that M. galloprovincialis cover caused a 5 to $10 \%$ decrease in annual yield of $P$. canaliculus. Woods et al. (2012) reported an average of 54\% biofouling organisms of the total rope biomass after 6 months. The reseeding of ropes reduced the amount of biofouling to $15 \%$ of the total rope biomass 6 months later. Innovations to reduce fouling 
are directed at reducing settlement. This can be done for instance by occupying $100 \%$ of the rope with mussels, or by manual removal of fouling or by using antifoulants (Fitridge et al. 2012).

Space restrictions in the coastal zone and developments such as off-shore windfarms, have speeded up developments towards off-shore mussel farms (Buck et al. 2004; Plew et al. 2005; Brenner et al. 2007; Ferreira et al. 2009; Van den Burg et al. 2017). However, off-shore conditions are much more challenging, also from a regulatory perspective (Corbin et al. 2017) and is an important driver of innovation in system design such as on the mooring of the systems (Ögmundarson et al. 2011), material use (Buck 2007) float design and food availability (Stevens et al. 2008).

\subsection{Efficient Use}

Culture efficiency is defined as how many units of end product (marked sized mussels) are harvested from one unit of resource (mussel seed). The index of culture efficiency is the average physical product APP (Ferreira et al. 2007), the Harvest to Seed Ratio (Newell 2007) or the relative biomass production (RBP) (Capelle et al. 2016). Efficient use is defined as by what means mussels growers can maximize their culture efficiency. Culture efficiency is biologically defined by the dynamics of growth and survival between resource and end product. There are several stages in the mussel culture cycle where management measures are or can be taken to improve growth and survival. These are: at seeding or stocking of seed, at relaying or thinning out and by predator control.

Survival of cultured mussels is dependent on the environment and on stress experienced in culture. In bottom mussel culture, large losses were found associated with seed handling (Calderwood et al. 2014; Capelle et al. 2016). Mussels are gregarious, but high mussel densities will increase competition and may result in substantial losses, that are witnessed in bouchot culture (Soletchnik et al. 2013), rope culture (Fréchette and Bacher 1998; Lauzon-Guay et al. 2005), but also in bottom culture (Capelle et al. 2014). In rope culture mussel losses can peak as a result of secondary settlement, when mussels that were initially attached (primary settlement), detach from the ropes in search for a different attachment substrate (South et al. 2017).

\subsubsection{Stocking Density}

Stocking mussels at optimal densities will enhance the culture efficiency. High mussel densities will increase competition and might result in substantial losses in bouchot culture (Soletchnik et al. 2013) and rope culture (Fréchette and Bacher 1998; Lauzon-Guay et al. 2005). Stocking in lower densities typically increases efficiency in rope culture (Cubillo et al. 2012), as well as in bottom culture (Capelle et al. 2016). Mussel size at stocking is an important parameter that effects culture 
efficiency: smaller mussels show higher losses (Lauzon-Guay et al. 2005), but have a higher biomass production potential (Petraitis 1995). However, stocking in low densities will expose more substrate for other species to settle on and enhances biofouling (South et al. 2017; Cubillo et al. 2015). Furthermore, when costs are considered higher biomass production at higher densities might compensate a reduction in quality and survival (Pérez-Camacho et al. 2013; Capelle et al. 2017). In several reports, mussel losses were attributed to seed handling. In bottom culture these losses are density dependent and can be reduced by applying a more homogeneous seeding pattern (Capelle et al. 2014) and by limiting the handling time (Calderwood et al. 2014). In rope culture, losses of 54\% were observed within 1 month after stocking (South et al. 2017).

\subsubsection{Relaying and Thinning Out}

Selecting the best site, with high food availability, may substantially increase culture productivity in mussel bottom culture (Herman et al. 1999; Ferreira et al. 2007). Feeding rates may increase up to a flow velocity of $0.8 \mathrm{~m} \mathrm{~s}^{-1}$ (Widdows et al. 2002); at a certain threshold, mussels may be dislodged, and as such, mussel farmers need to optimize production within this range. In bottom mussel farming, relaying is common practice. Mussels are often kept on sheltered plots over winter and relayed to plots with good growing conditions in spring. Mussels might also be relayed from intertidal plots to deeper plots, to stimulate survival and growth (Beadman et al. 2003). Mussels that are transplanted between areas may require physiological adaptations. Especially in the size of the gills that are used to capture particles and in the size of the labial palps that are used to sort particles into edible and not edible (Bayne 2004). In areas with high turbidity, gills are small and labial palps are large (Theisen 1982). In mussels, an adaptation in the gill-to-palp ratio was observed after transplantation to sites with different turbidity values (Essink and Bos 1985; Payne et al. 1995). After a transplantation experiment between two systems in southern England, it took 2 months for the mussels to adapt the gill-to-palp ratio to the new environment (Widdows et al. 1984).

Ropes or nets have limited attachment area, hence mussels will start to fall off when mussel densities are too high. Self-thinning occurs when mussel biomass increases and space or food becomes limiting, causing a reduction in growth and survival (Alunno-Bruscia et al. 2000; Guiñez et al. 2005). Manual thinning out on ropes in raft culture in Galicia Spain occurs after 4-7 months of growing when the mussels reach 4-5 cm (Cubillo et al. 2012). In the thinning process mussels are detached from the ropes and re-socked in a lower density around a new rope. During the thinning process size grading can take place that will result in a more uniform mussel size at harvest and in less mussel discards (Pérez Camacho et al. 1991). The thinning process in Spain was associated with mussel losses (Pérez Camacho et al. 1991, 2013). 


\subsubsection{Predator Control}

Mussels are not only providing goods for human consumption, but also for a range of other species, some of which depend on them as a food source. Several management measures to prevent predation in bouchot culture are described by DardignacCorbeil (1975): (1) Crabs (Carcinus meanas, Maja brachydactyla) which predate on the bouchot mussels, can be prevented by placing a sheet around the bouchots. (2) Predation by birds (e.g. gulls or molluscivorous ducks) on mussels on bouchots can be reduced by using nylon threads to prevent the birds landing. (3) When starfish and mollusc drilling snails (Nucella lapillus) are present in high densities and predation levels are high they need to be manually removed.

Predation may exert a top down limitation on production. Especially, in bottom culture, because mussel plots are accessible for benthic predators as well as for fish and birds. Intertidal mussels are preyed upon by shore crabs and birds (oystercatchers, herring gulls), while subtidal mussels are preyed upon by shore crabs, sea stars and molluscivorous (diving) ducks. The number of sea stars on culture plots is reduced by freshwater treatment and there is a selective fishery on sea stars with sea star mops (Netherlands, United Kingdom, Germany, and Ireland) and purse-seines (Denmark Petersen et al. 2016). Freshwater treatment is applied before seeding when mussels are in the vessels' hold; the process consists of the joint exposure of mussels and associated sea stars to freshwater for several hours Mussels will keep their shells shut, while sea stars are unable to protect themselves against osmotic stress and will not survive. Sea star mops are made of fuzzy rope entwined around small chains that are towed over the mussel plots, which ensnares the sea stars thereby enabling removal. The efficiency of sea star removal by mops was estimated in a case study in Belfast Lough in Northern Ireland. The results show a large variation in the catch efficiency (4-78\%), while the mean sea star reduction applying this method was 27\% (Calderwood et al. 2016).

When Davies et al. (1980) tested the effect of exclusion of shore crabs in newly formed intertidal mussel beds on a scale of $800 \mathrm{~m}^{2}$; they found that exclusion of shore crabs resulted in a 400-500\% increase in yield over a period of 2 years. Experiments have been conducted on selective crab fisheries in a comparative study on culture plots in the Wadden Sea, but no differences in survival between culture plots where crabs were removed vs. where no crab fishery took place could be found (Kamermans et al. 2010). Therefore, exclusion of shore crabs seems to be more effective than a selective fishery.

Rope or net culture of mussels have the advantage above bottom culture that benthic predators cannot reach the mussels directly. Predation by mobile predators on mussels in raft or longline culture are therefore limited to molluscivorous birds and fishes. However, predators with pelagic larvae can settle between the mussels. Sea stars commonly settle in long-line farms and marine flatworms (Turbellaria or Plathyhelminthes) can infest the mussels and cause substantial losses (Galleni et al. 1980; Robledo et al. 1994). Ducks such as eider ducks that primarily feed on mussels can cause extensive damage to longline mussel cultures (Dunthorn 1971; 
Žydelis et al. 2009). In Maine (USA) mussels are protected by nets placed around the mussel rafts (Newell and Richardson 2014). Mussel ropes and nets are very attractive for a range of fish species (Šegvić-Bubić et al. 2011). In the Mediterranean, sea breams are considered a pest that is very difficult to handle and may require nets as physical barriers (Prou and Goulletquer 2002).

\subsubsection{Other Loss Factors}

Sometimes environmental events result in mussel losses and the only option mussel growers have are mitigation measures. Environmental factors such as harmful algal blooms (HABs) (Peperzak and Poelman 2008) or diseases and parasites (mainly limited to Myticola intestinalis in Mytilidea (Bower et al. 1994) and Bucephalus sp. in Perna (da Silva et al. 2002), on bouchot mussels heat stress might increase losses up to $70 \%$ (Soletchnik et al. 2013). Ice scour is a catastrophic event for intertidal mussel populations (Donker et al. 2015) However, not all mussel losses can be explained. In recent years, abnormal high mussel losses were observed at mussel production sites in the Atlantic coast in France (2014-2016) and at the Oosterschelde estuary in the Netherlands (2016). Mussel meat at sites with abnormal mortality rates contained higher densities of granulomas, inflammatory inclusions at the Atlantic coast in France, suggesting that the mussels experienced stress (Robert and Soletchnik 2016). In a follow-up study, climatic events tied to climate change that affected abiotic conditions, but also algal compositions and timing of blooms were linked to higher mortality events, although a conclusion is still lacking (Travers et al. 2016; Soletchnik et al. 2017). Elevation of atmosphere and sea surface temperatures resulted in shifts of the geographical distribution of mussels to colder areas (Berge et al. 2005) and catastrophic summer mortalities at intertidal sites due to heating stress (Jones et al. 2010).

\subsubsection{Differences in Efficiency Between Species and Culture Methods}

Reported culture efficiencies are shown in Table 3.2, expressed as Relative Biomass Production (RBP): the biomass of harvestable product from one biomass unit of seed. It appears from this table that bottom culture is the least efficient, which can be explained by the high density dependent losses, predation pressure and dislodgement vulnerability for the mussels in this type of culture. Major improvements are expected in reducing handling stress and density dependent losses (Capelle et al. 2017). Production efficiencies of mussels from the Perna species are around $5 \mathrm{~kg}$ of harvestable product from $1 \mathrm{~kg}$ of seed, despite having the largest growth rates. It seems that survival rates for Perna mussels are lower than for other rope or raft 


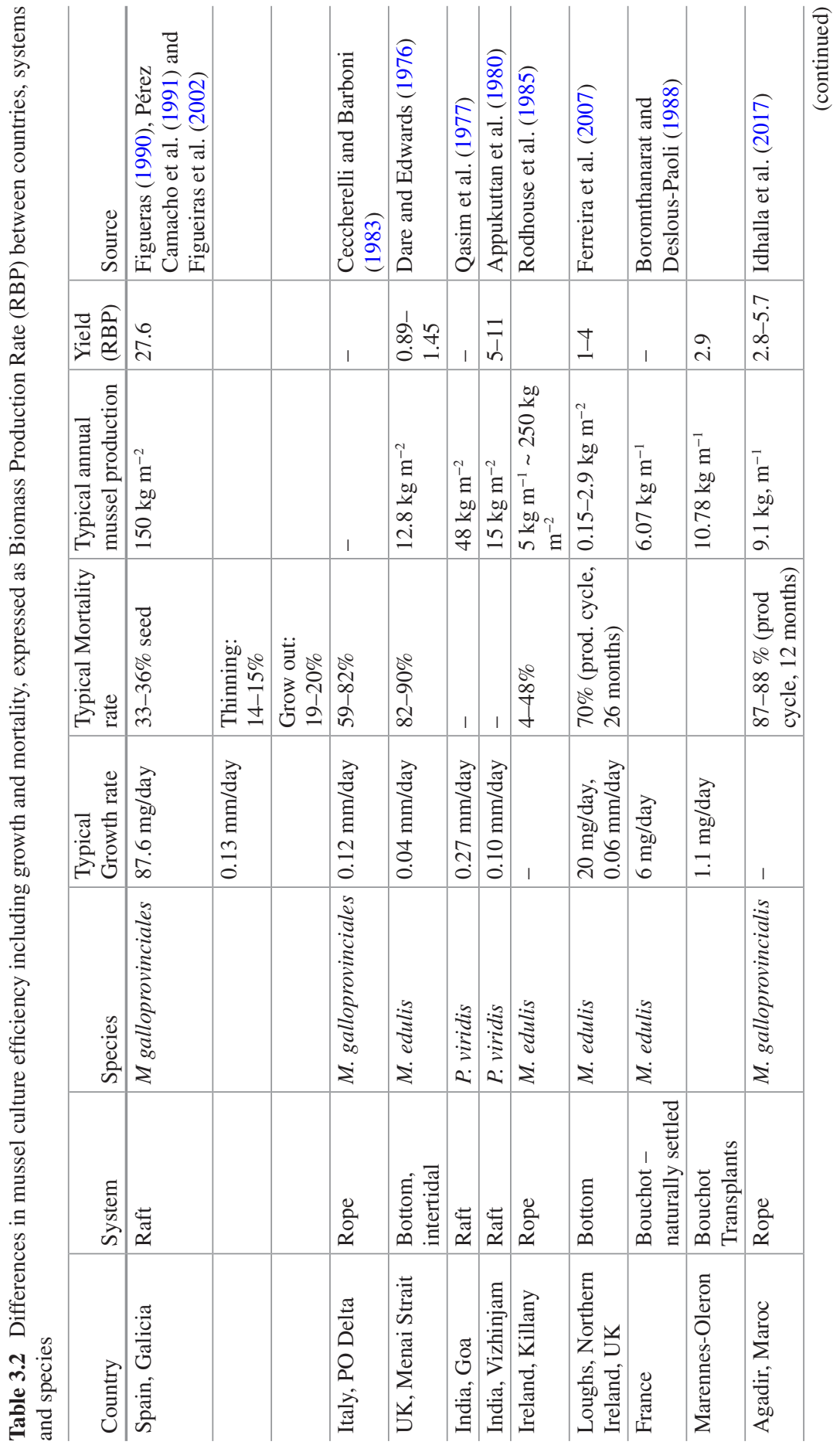




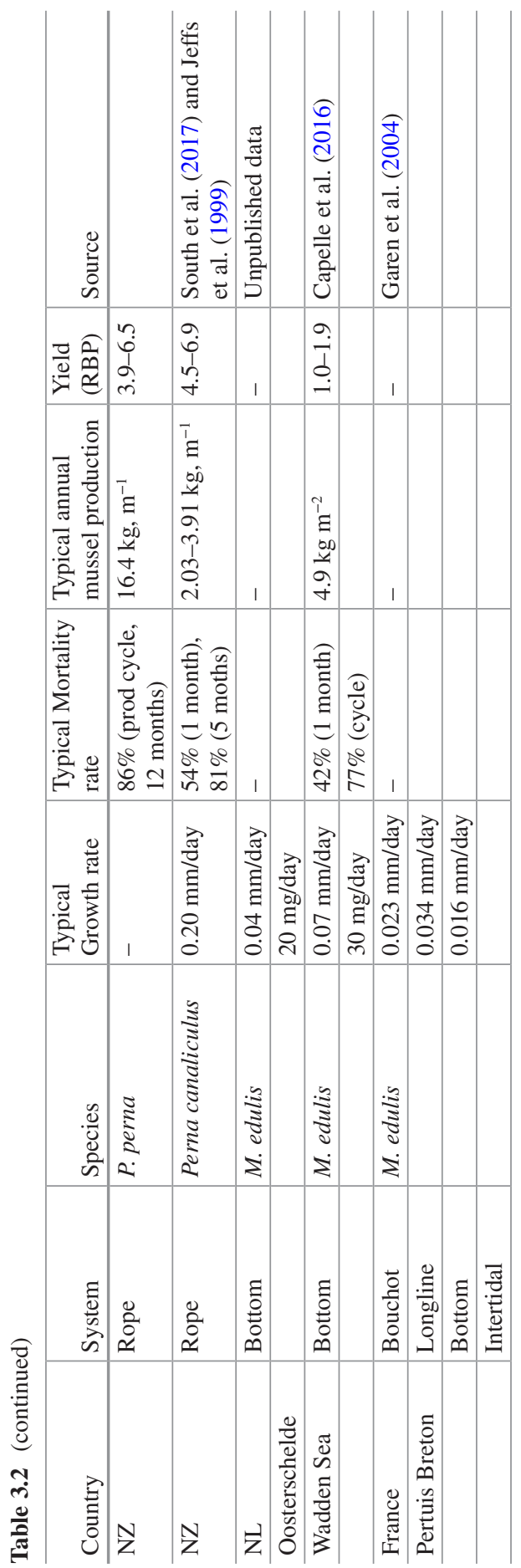


grown mussel families, and are in fact comparable with mussel bottom culture. Note that RBPs of Perna mussels are higher than for mussel bottom culture, caused by faster growth rates of Perna mussels. It is reported that detachment from ropes is a major problem during the grow out of Perna mussels (South et al. 2017; Petes et al. 2007). Bouchot culture is slightly more efficient than bottom culture but less efficient than rope culture. This can be explained by the low growth rates which are experienced in this type of intertidal culture, and the fact that bouchot mussels are more vulnerable to benthic predators than rope cultured mussels. Raft culture of $M$. galloprovincialis in Spain is a very effective culture. High yields are reached because the culture starts with small seeds which increase in weight tenfold when they are thinned out and the mussel seed is re-socked in a lower density over three new ropes (Pérez Camacho et al. 1991).

\subsection{Conclusions}

The starting material for mussel culture is wild harvest of seed, use of SMC or hatchery production. Fished seed is mostly used in bottom culture, while longline and raft culture predominantly use seed collectors. Hatchery seed is only used in longline culture. Most research concerning spat collection deals with comparisons of different types of seed collectors, settlement cues and problems with biofouling. Optimising the timing of deployment of the collectors and the timing of harvest can increase the yield of seed collectors. Hatchery seed is more expensive, but hatcheries provide the opportunity for selective breeding and triploid production giving the product an added value. The challenge is to bring hatchery production costs more in line with the potential sale value of mussel seed. Monitoring can give insight in whether genetic diversity of collector seed or hatchery seed is negatively affected.

Efficiency in use of mussel seed shows large differences between species, regions and culture techniques. Survival rates seem higher for mussels from the Mytilus genus, than for mussels from the Perna genus. Several key processes were identified that can explain these differences. Losses differ because of different predation pressures or because of differences between substrate and the relationship between food, space and density. Other sources of losses can be related to anomalous, environmental events, such as storms or heat stress. Losses due to such events might become more common in the near future, for example, with the effects of climate change. Growth rates differ between species and between production systems. In general, mussels form the Perna genus display higher growth rates than mussels from the Mytilus genus. Rope and raft culture is more efficient in terms of yield than bouchot, while bouchot seems a little more efficient than bottom culture.

For bottom culture, seed from SMCs has gradually become an important seed source complementary to seed from wild harvest. However, seed is more expensive from SMCs than from wild harvest and several research programs were carried out towards methods to increase efficient use. Technical developments in off-bottom culture mainly concern optimizing system designs and are particularly innovative in 
the way in which they relate system design to optimal feeding rates and dealing with harsh hydrodynamic conditions. Spatial conflicts in traditional culture areas may provoke the development of off-shore culture implying risk of exposure to hydrodynamic stress.

Acknowledgements We would like to thank Nigel Keeley and Tore Strohmeier for their constructive review of the manuscript.

\section{References}

Abalde SL, Fuentes J, González-Fernández Á (2003) Identification of Mytilus galloprovincialis larvae from the Galician rias by mouse monoclonal antibodies. Aquaculture 219:545-559

Aghzar A, Talbaoui M, Benajiba M, Presa P (2012) Influence of depth and diameter of rope collectors on settlement density of Mytilus galloprovincialis spat in Baie de M'diq (Alboran Sea). Mar Freshw Behav Physiol 45:51-61

Alunno-Bruscia M, Petraitis PS, Bourget E, Fréchette M (2000) Body size-density relationship for Mytilus edulis in an experimental food-regulated situation. Oikos 90:28-42

Appukuttan K, Nair TP, Joseph M, Thomas K (1980) Culture of brown mussel at Vizhinjam. CMFRI Bull 29:30-32

Aure J, Strohmeier T, Strand Ø (2007) Modelling current speed and carrying capacity in long-line blue mussel (Mytilus edulis) farms. Aquac Res 38:304-312

Aypa SM (1990) Mussel culture. Fisheries and Aquaculture Department, FAO, Rome

Bayne BL (2004) Phenotypic flexibility and physiological tradeoffs in the feeding and growth of marine bivalve molluscs. Integr Comp Biol 44:425-432

Beadman HA, Caldow RWG, Kaiser MJ, Willows RI (2003) How to toughen up your mussels: using mussel shell morphological plasticity to reduce predation losses. Mar Biol 142:487-494

Beaumont A, Gjedrem T, Moran P (2006) Genetic effects of domestication, culture and breeding of fish and shellfish, and their impacts on wild populations. Blue mussel - Mytilus edulis and Mediterranean mussel - M. galloprovincialis. In: Svåsand TCD, García-Vázquez E, Verspoor E (eds) Evaluation of genetic impact of aquaculture activities on native populations: a European network, pp 83-90. GENIMPACT final report (EU contract n. RICA-CT-2005-022802). http:// genimpact.imr.no/

Berge J, Johnsen G, Nilsen F, Gulliksen B, Slagstad D (2005) Ocean temperature oscillations enable reappearance of blue mussels Mytilus edulis in Svalbard after a 1000 year absence. Mar Ecol Prog Ser 303:167-175

Blanco Garcia A, Kamermans P (2015) Optimization of blue mussel (Mytilus edulis) seed culture using recirculation aquaculture systems. Aquac Res 46:977-986

Boromthanarat S, Deslous-Paoli JM (1988) Production of Mytilus edulis L. reared on bouchots in the Bay of Marennes-Orleon: comparison between two methods of culture. Aquaculture 72:255-263

Bos OG, Hendriks IE, Strasser M, Dolmer P, Kamermans P (2006) Estimation of food limitation of bivalve larvae in coastal waters of North-Western Europe. J Sea Res 55:191-206

Bower SM, McGladdery SE, Price IM (1994) Synopsis of infectious diseases and parasites of commercially exploited shellfish. Annu Rev Fish Dis 4:1-199

Brenner M, Buck BH, Köhler A (2007) New concept combines offshore wind farms, mussel cultivation. Glob Aquacult Advocate 10(1):79-81

Buck BH (2007) Experimental trials on the feasibility of offshore seed production of the mussel Mytilus edulis in the German Bight: installation, technical requirements and environmental conditions. Helgol Mar Res 61:87-101 
Buck BH, Krause G, Rosenthal H (2004) Multifunctional use, environmental regulations and the prospect of offshore co-management: potential for and constraints to extensive open ocean aquaculture development within wind farms in Germany. Ocean Coast Manag 47:95-122

Calderwood J, O'Connor NE, Sigwart J, Roberts D (2014) Determining optimal duration of seed translocation periods for benthic mussel (Mytilus edulis) cultivation using physiological and behavioural measures of stress. Aquaculture 434:288-295

Calderwood J, O'Connor NE, Roberts D (2016) Efficiency of starfish mopping in reducing predation on cultivated benthic mussels (Mytilus edulis Linnaeus). Aquaculture 452:88-96

Camara M, Symonds J (2014) Genetic improvement of New Zealand aquaculture species: programmes, progress and prospects. N Z J Mar Freshw Res 48:466-491

Capelle JJ (2017) Production efficiency of mussel bottom culture. Wageningen University, Wageningen, p 240

Capelle JJ, Wijsman JWM, Schellekens T, van Stralen MR, Herman PMJ, Smaal AC (2014) Spatial organisation and biomass development after relaying of mussel seed. J Sea Res 85:395-403

Capelle JJ, Wijsman JWM, van Stralen MR, Herman PMJ, Smaal AC (2016) Effect of seeding density on biomass production in mussel bottom culture. J Sea Res 85:395-403

Capelle JJ, van Stralen MR, Wijsman JWM, Herman PMJ, Smaal AC (2017) Population dynamics of subtital mussels (Mytilus edulis) and the impact of cultivation. Aquac Environ Interact 9:155-168

Carrasco AV (2015) Pre-feasibility study for the installation of a Chilean Mussel Mytilus chilensis (Hupé, 1854) seed hatchery in the lakes region, Chiles. Fish Aquac J 3:102

Ceccherelli VU, Barboni A (1983) Growth, survival and yield of Mytilus galloprovincialis Lamk. on fixed suspended culture in a bay of the Po River Delta. Aquaculture 34:101-114

Çelik MY, Karayücel S, Karayücel İ, Eyüboğlu B, Öztürk R (2016) Settlement and growth of the mussels (Mytilus galloprovincialis, Lamarck, 1819) on different collectors suspended from an offshore submerged longline system in the Black Sea. Aquac Res 47:3765-3776

Christensen HT (2012) Area-intensive bottom culture production of blue mussels, Mytilus edulis (L.), PhD dissertation, DTU aqua (Danmarks Tekniske Universitet), Denmark

Christensen HT, Dolmer P, Hansen BW, Holmer M, Kristensen LD, Poulsen LK, Stenberg C, Albertsen CM, Støttrup JG (2015) Aggregation and attachment responses of blue mussels, Mytilus edulis - impact of substrate composition, time scale and source of mussel seed. Aquaculture 435:245-251

Corbin JS, Holmyard J, Lindell S (2017) Regulation and permitting of standalone and co-located open ocean aquaculture facilities. In: Aquaculture perspective of multi-use sites in the open ocean. Springer, Dordrecht, pp 187-229

Cranford PJ, Li W, Strand Ø, Strohmeier T (2008) Phytoplankton depletion by mussel aquaculture: high resolution mapping, ecosystem modeling and potential indicators of ecological carrying capacity. Ecological carrying capacity in shellfish aquaculture. ICES CM, pp 1-5

Cubillo AM, Peteiro LG, Fernández-Reiriz MJ, Labarta U (2012) Influence of stocking density on growth of mussels (Mytilus galloprovincialis) in suspended culture. Aquaculture 342-343:103-111

Cubillo AM, Fuentes-Santos I, Labarta U (2015) Interaction between stocking density and settlement on population dynamics in suspended mussel culture. J Sea Res 95:84-94

da Silva PM, ARM M, Barracco MA (2002) Effects of Bucephalus sp. (Trematoda: Bucephalidae) on Perna perna mussels from a culture station in Ratones Grande Island, Brazil. J Invertebr Pathol 79:154-162

Dardignac-Corbeil M-J (1975) La culture des moules sur bouchots. Science et Pêche 244:1-10

Dare PJ, Edwards DB (1976) Experiments on the survival, growth and yield of relaid seed mussels (Mytilus edulis L.) in the Menai Straits, North Wales. J Cons Int Explor Mer 37:16-28

Davies GP, Dare PJ, Edwards DB (1980) Fenced enclosures for the protection of seed mussels (Mytilus edulis L.) from predation by shore crabs (Carcinus maenas L.). Fisheries research technical report, 56

Díaz-Puente B, Miñambres M, Rosón G, Aghzar A, Presa P (2016) Genetic decoupling of spat origin from hatchery to harvest of Mytilus galloprovincialis cultured in suspension. Aquaculture 460:124-135 
Donker JJA, van der Vegt M, Hoekstra P (2015) Erosion of an intertidal mussel bed by ice- and wave-action. Cont Shelf Res 106:60-69

Drapeau A, Comeau LA, Landry T, Stryhn H, Davidson J (2006) Association between longline design and mussel productivity in Prince Edward Island, Canada. Aquaculture 261:879-889

Dunthorn A (1971) The predation of cultivated mussels by eiders. Bird Study 18:107-112

Erlandson JM (1988) The role of shellfish in prehistoric economies: a protein perspective. Am Antiq 53:102-109

Essink K, Bos AH (1985) Growth of three bivalve molluscs transplanted along the axis of the Ems estuary. Neth J Sea Res 19:45-51

Ferreira JG, Hawkins AJS, Monteiro P, Service M, Moore H, Edwards A, Gowen R, Lourenco P, Mellor A, Nunes JP, Pascoe PL, Ramos L, Sequeira A, Simas T, Strong J (2007) SMILE sustainable mariculture in northern Irish lough ecosystems - Assesment of carrying capacity for environmental sustainable shelfish culture in Carlingford Lough, Strangford Lough, Belfast Lough, Larne Lough and Lough Foyle. IMAR - Institute of Marine Research, p 100

Ferreira J, Sequeira A, Hawkins A, Newton A, Nickell T, Pastres R, Forte J, Bodoy A, Bricker S (2009) Analysis of coastal and offshore aquaculture: application of the FARM model to multiple systems and shellfish species. Aquaculture 289:32-41

Figueiras F, Labarta U, Reiriz MF (2002) Coastal upwelling, primary production and mussel growth in the Rías Baixas of Galicia. In: Sustainable increase of marine harvesting: fundamental mechanisms and new concepts. Springer, Dordrecht, pp 121-131

Figueras A (1990) Mussel culture in Spain. Mar Behav Physiol 16:177-207

Filgueira R, Brown MS, Comeau LA, Grant J (2015) Predicting the timing of the pediveliger stage of Mytilus edulis based on ocean temperature. J Molluscan Stud 81:269-273

Fitridge I, Dempster T, Guenther J, de Nys R (2012) The impact and control of biofouling in marine aquaculture: a review. Biofouling 28:649-669

Forrest BM, Atalah J (2017) Significant impact from blue mussel Mytilus galloprovincialis biofouling on aquaculture production of green-lipped mussels in New Zealand. Aquac Environ Interact 9:115-126

Fréchette M, Bacher C (1998) A modelling study of optimal stocking density of mussel populations kept in experimental tanks. J Exp Mar Biol Ecol 219:241-255

Fréchette M, Lefaivre D (1995) On self-thinning in animals. Oikos 73:425-428

Gale SL, Burritt DJ, Tervit HR, Adams SL, McGowan LT (2014) An investigation of oxidative stress and antioxidant biomarkers during Greenshell mussel (Perna canaliculus) oocyte cryopreservation. Theriogenology 82:779-789

Galleni L, Tongiorgi P, Ferrero E, Salghetti U (1980) Stylochus mediterraneus (Turbellaria: Polycladida), predator on the mussel Mytilus galloprovincialis. Mar Biol 55:317-326

Garen P, Robert S, Bougrier S (2004) Comparison of growth of mussel, Mytilus edulis, on longline, pole and bottom culture sites in the Pertuis Breton, France. Aquaculture 232:511-524

Grant J, Bacher C, Cranford PJ, Guyondet T, Carreau M (2008) A spatially explicit ecosystem model of seston depletion in dense mussel culture. J Mar Syst 73:155-168

Gribben PE, Jeffs AG, de Nys R, Steinberg PD (2011) Relative importance of natural cues and substrate morphology for settlement of the New Zealand Greenshell ${ }^{\mathrm{TM}}$ mussel, Perna canaliculus. Aquaculture 319:240-246

Gui Y, Zamora L, Dunphy B, Jeffs A (2016) Understanding the ontogenetic changes in particle processing of the greenshell ${ }^{\mathrm{TM}}$ mussel, Perna canaliculus, in order to improve hatchery feeding practices. Aquaculture 452:120-127

Guiñez R (2005) A review on self-thinning in mussels. Revista de Biologia Marina y Oceanografia 40:1-6

Guiñez R, Petraitis PS, Castilla JC (2005) Layering, the effective density of mussels and massdensity boundary curves. Oikos 110:186-190

Gurney-Smith HJ, Wade AJ, Abbott CL (2017) Species composition and genetic diversity of farmed mussels in British Columbia, Canada. Aquaculture 466:33-40

Herman P, Middelburg J, Van de Koppel J, Heip C (1999) Ecology of estuarine macrobenthos. Adv Ecol Res 29:195-240 
Idhalla M, Nhhala H, Kassila J, Ait Chattou EM, Orbi A, Moukrim A (2017) Comparative production of two mussel species (Perna perna and Mytilus galloprovincialis) reared on an offshore submerged longline system in Agadir, Morocco. Int J Sci Eng Res 8:1

Jacobs P, Beauchemin C, Riegman R (2014) Growth of juvenile blue mussels (Mytilus edulis) on suspended collectors in the Dutch Wadden Sea. J Sea Res 85:365-371

Jeffs AG, Holland RC, Hooker SH, Hayden BJ (1999) Overview and bibliography of research on the greenshell mussel, Perna canaliculus, from New Zealand waters. J Shellfish Res 18:347-360

Jones SJ, Lima FP, Wethey DS (2010) Rising environmental temperatures and biogeography: poleward range contraction of the blue mussel, Mytilus edulis L., in the western Atlantic. J Biogeogr 37:2243-2259

Kamermans P, Smaal AC (2002) Mussel culture and cockle fisheries in The Netherlands: finfing a balance between economy and ecology. J Shellfish Res 21:509-517

Kamermans P, Brummelhuis E, Smaal A (2002) Use of spat collectors to enchange supply of seed for bottom culture of blue mussels (Mytilus edulis) in the Netherlands. World Aquacult 33:12-15

Kamermans P, de Jong ML, van Hoppe M (2010) PRODUS 1 d: rendement MZI zaad op percelen: effect van wegvissen van krabben - perceelproef 2009. IMARES, Yerseke, Report C075/10

Kamermans P, Galley T, Boudry P, Fuentes J, McCombie H, Batista F, Blanco A, Dominguez L, Cornette F, Pincot L (2013) Blue mussel hatchery technology in Europe. In: Advances in aquaculture hatchery technology. Elsevier, New York, pp 339-373

Kamermans P, Smit CJ, Wijsman JWM, Smaal AC (2014) Meerjarige effect-en productiemetingen aan MZI's in de Westelijke Waddenzee, Oosterschelde en Voordelta: samenvattend eindrapport. IMARES. Report C191/13

Kautsky N, Johannesson K, Tedengren M (1990) Genotypic and phenotypic differences between Baltic and North Sea populations of Mytilus edulis evaluated through reciprocal transplantations. I. Growth and morphology. Mar Ecol Prog Ser 59:203-210

Larraín MA, Díaz NF, Lamas C, Uribe C, Jilberto F, Araneda C (2015) Heterologous microsatellitebased genetic diversity in blue mussel (Mytilus chilensis) and differentiation among localities in southern Chile. Lat Am J Aquat Res 43:998

Lauzon-Guay J-S, Dionne M, Barbeau MA, Hamilton DJ (2005) Effects of seed size and density on growth, tissue-to-shell ratio and survival of cultivated mussels (Mytilus edulis) in Prince Edward Island, Canada. Aquaculture 250:652-665

Locke A, Carman M (2009) Ecological interactions between the vase tunicate (Ciona intestinalis) and the farmed blue mussel (Mytilus edulis) in Nova Scotia, Canada. Aquat Invasions 4:177-187

Newell CR (2007) Case study 1 - factors which influence mussel production on bottom leases. In: SMILE - Sustainable Mariculture in northern Irish Lough Ecosystems - Assesment of carrying capacity for environmental sustainable Shelfish culture in Carlingford lough, Strangford lough, Belfast lough, Larne lough and lough Foyle. IMAR - Institute of Marine Research, p 100

Newell CR, Richardson J (2014) The effects of ambient and aquaculture structure hydrodynamics on the food supply and demand of mussel rafts. J Shellfish Res 33:257-272

Newell CR, Campbell DE, Gallagher SM (1998) Development of the mussel aquaculture lease site model MUSMOD $\odot$ : a field program to calibrate model formulations. J Exp Mar Biol Ecol 219:143-169

Ögmundarson Ó, Holmyard J, Pórðarson G, Sigurðsson F, Gunnlaugsdóttir H (2011) Offshore aquaculture farming - report from the initial feasibility study and market requirements for the innovations from the project. Icelandic Food and Biotech, Reykjavík

Payne BS, Miller AC, Jin L (1995) Palp to gill area ratio of bivalves: a sensitive indicator of elevated suspended solids. Regul Rivers Res Manag 11:193-200

Peperzak L, Poelman M (2008) Mass mussel mortality in The Netherlands after a bloom of Phaeocystis globosa (prymnesiophyceae). J Sea Res 60:220-222

Pérez Camacho A, González R, Fuentes J (1991) Mussel culture in Galicia (N.W. Spain). Aquaculture 94:263-278 
Pérez-Camacho A, Labarta U, Vinseiro V, Fernández-Reiriz MJ (2013) Mussel production management: raft culture without thinning-out. Aquaculture 406:172-179

Petersen AJK, Gislason H, Fitridge I, Saurel C, Degel H, Nielsen CF (2016) Fiskeri efter søstjerner i Limfjorden. Fagligt grundlag for en forvaltningsplan. Institut for Akvatiske Ressourcer, Danmarks Tekniske Universitet

Petes LE, Menge BA, Murphy GD (2007) Environmental stress decreases survival, growth, and reproduction in New Zealand mussels. J Exp Mar Biol Ecol 351:83-91

Petraitis PS (1995) The role of growth in maintaining spatial dominance by mussels (Mytilus edulis). Ecology 76:1337-1346

Philippart CJ, Amaral A, Asmus R, van Bleijswijk J, Bremner J, Buchholz F, Cabanellas-Reboredo M, Catarino D, Cattrijsse A, Charles F (2012) Spatial synchronies in the seasonal occurrence of larvae of oysters (Crassostrea gigas) and mussels (Mytilus edulis/galloprovincialis) in European coastal waters. Estuar Coast Shelf Sci 108:52-63

Plew DR, Stevens CL, Spigel RH, Hartstein ND (2005) Hydrodynamic implications of large offshore mussel farms. IEEE J Ocean Eng 30:95-108

Prou J, Goulletquer P (2002) The French mussel industry: present status and perspectives. Bull Aquac Assoc Can 102:17-23

Qasim S, Parulekar A, Harkantra S, Ansari Z, Nair A (1977) Aquaculture of green mussel Mytilus viridis L.: cultivation on ropes from floating rafts. Indian J Mar Sci 6:15-25

Ramsay A, Davidson J, Landry T, Stryhn H (2008) The effect of mussel seed density on tunicate settlement and growth for the cultured mussel, Mytilus edulis. Aquaculture 275:194-200

Ranjith Kumar R, Vijayan K, Thomas P, Mohamed K, Gopalakrishnan A (2015) Identification of brown mussel (Perna indica) larvae using molecular tool. Indian J Fish 62:128-131

Reguera B, Riobó P, Rodríguez F, Díaz PA, Pizarro G, Paz B, Franco JM, Blanco J (2014) Dinophysis toxins: causative organisms, distribution and fate in shellfish. Mar Drugs 12:394-461

Robert S, Soletchnik P (2016) Réseau national d'observation de la moule bleue, MYTILOBS/ Campagne 2015

Robledo J, Caceres-Martinez J, Sluys R, Figueras A (1994) The parasitic turbellarian Urastoma cyprinae (Platyhelminthes: Urastomidae) from blue mussel Mytilus galloprovincialis in Spain: occurrence and pathology. Dis Aquat Org 18:203-210

Rodhouse PG, Roden CM, Hensey MP, Ryan TH (1985) Production of mussels, Mytilus edulis, in suspended culture and estimates of carbon and nitrogen flow: Killary Harbour, Ireland. J Mar Biol Assoc U K 65:55-68

Rosland R, Bacher C, Strand Ø, Aure J, Strohmeier T (2011) Modelling growth variability in longline mussel farms as a function of stocking density and farm design. J Sea Res 66:318-330

Šegvić-Bubić T, Grubišić L, Karaman N, Tičina V, Jelavić KM, Katavić I (2011) Damages on mussel farms potentially caused by fish predation - self service on the ropes? Aquaculture 319:497-504

Sievers M, Fitridge I, Dempster T, Keough MJ (2013) Biofouling leads to reduced shell growth and flesh weight in the cultured mussel Mytilus galloprovincialis. Biofouling 29:97-107

Smaal AC (2002) European mussel cultivation along the Atlantic coast: production status, problems and perspectives. Hydrobiologia 484:89-98

Soletchnik P, Robert S, Le Moine O (2013) Suivi expérimental de la croissance de la moule, Mytilus edulis, sur les bouchots des Pertuis Charentais entre 2000 et 2010. Etude des performances de croissance en liens avec l'environnement des élevages. http://archimer.ifremer.fr/ doc/00120/23097/

Soletchnik P, Le Moine O, Polsenaere P (2017) Evolution de l'environnement hydroclimatique du bassin de Marennes-Oléron dans le contexte du changement global. http://archimer.ifremer.fr/ doc/00387/49815/

South PM, Floerl O, Jeffs AG (2017) Differential effects of adult mussels on the retention and finescale distribution of juvenile seed mussels and biofouling organisms in long-line aquaculture. Aquac Environ Interact 9:239-256

Stevens C, Plew D, Hartstein N, Fredriksson D (2008) The physics of open-water shellfish aquaculture. Aquac Eng 38:145-160 
Stirling H, Okumuş İ (1994) Growth, mortality and shell morphology of cultivated mussel (Mytilus edulis) stocks cross-planted between two Scottish Sea lochs. Mar Biol 119:115-123

Strohmeier T, Aure J, Duinker A, Castberg T, Svardal A, Strand Ø (2005) Flow reduction, seston depletion, meat content and distribution of diarrhetic shellfish toxins in a long-line blue mussel (Mytilus edulis) farm. J Shellfish Res 24:15-23

Theisen BF (1982) Variation in size of gills, labial palps, and adductor muscle in Mytilus edulis L. (Bivalvia) from Danish waters. Ophelia 21:49-63

Travers M-A, Pepin J-F, Soletchnik P, Guesdon S, Le Moine O (2016) Mortalités de moules bleues dans les Pertuis Charentais: description et facteurs liés-MORBLEU. http://archimer.ifremer. fr/doc/00324/43539/

Tremblay R, Landry T, Leblanc N, Pernet F, Barkhouse C, Sévigny J-M (2011) Physiological and biochemical indicators of mussel seed quality in relation to temperatures. Aquat Living Resour 24:273-282

van den Burg S, Kamermans P, Blanch M, Pletsas D, Poelman M, Soma K, Dalton G (2017) Business case for mussel aquaculture in offshore wind farms in the North Sea. Mar Policy $85: 1-7$

Waldbusser GG, Hales B, Langdon CJ, Haley BA, Schrader P, Brunner EL, Gray MW, Miller CA, Gimenez I (2015) Saturation-state sensitivity of marine bivalve larvae to ocean acidification. Nat Clim Chang 5:273-280

Wang H, Li X, Wang M, Clarke S, Gluis M (2014) The development of oocyte cryopreservation techniques in blue mussels Mytilus galloprovincialis. Fish Sci 80:1257-1267

Wang X-x, Swift MR, Dewhurst T, Tsukrov I, Celikkol B, Newell C (2015) Dynamics of submersible mussel rafts in waves and current. China Ocean Eng 29:431-444

Widdows J, Donkin P, Salkeld PN, Cleary JJ, Lowe DM, Evans SV, Thompson PE (1984) Relative importance of environmental factors in determining physiological differences between two populations of mussels (Mytilus edulis). Mar Ecol Prog Ser 17:33-47

Widdows J, Lucas JS, Brinsley MD, Salkeld PN, Staff FJ (2002) Investigation of the effects of current velocity on mussel feeding and mussel bed stability using an annular flume. Helgol Mar Res 56:3-12

Woods CM, Floerl O, Hayden BJ (2012) Biofouling on Greenshell ${ }^{\mathrm{TM}}$ mussel (Perna canaliculus) farms: a preliminary assessment and potential implications for sustainable aquaculture practices. Aquac Int 20:537-557

Žydelis R, Esler D, Kirk M, Sean Boyd W (2009) Effects of off-bottom shellfish aquaculture on winter habitat use by molluscivorous sea ducks. Aquat Conserv Mar Freshwat Ecosyst 19:34-42

Open Access This chapter is licensed under the terms of the Creative Commons Attribution 4.0 International License (http://creativecommons.org/licenses/by/4.0/), which permits use, sharing, adaptation, distribution and reproduction in any medium or format, as long as you give appropriate credit to the original author(s) and the source, provide a link to the Creative Commons license and indicate if changes were made.

The images or other third party material in this chapter are included in the chapter's Creative Commons license, unless indicated otherwise in a credit line to the material. If material is not included in the chapter's Creative Commons license and your intended use is not permitted by statutory regulation or exceeds the permitted use, you will need to obtain permission directly from the copyright holder.

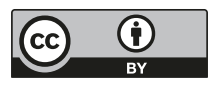

